\title{
Response of several apple tree cultivars to chemical thinner sprays
}

\author{
George Ouma ${ }^{a \star}$, Frank Matta ${ }^{b}$
}

a Department of horticulture, Maseno University, PO box 333, Maseno, Kenya gouma@swiftkisumu.com

${ }^{b}$ Department of Plant and Soil Sciences,

Mississippi State University, Mississippi State, MS 39762, USA
* Correspondence and reprints

Fruits, 2003, vol. 58, p. 275-281 (C) 2003 Cirad/EDP Sciences All rights reserved

DOI: 10.1051/fruits:2003015

RESUMEN ESPAÑOL, p. 281

\section{Response of several apple tree cultivars to chemical thinner sprays.}

Abstract - Introduction. The chemical fruit thinning of apple trees carried out after flowering is a current practice used to improve fruit size and quality, to ensure the return of flowering and to reduce the biennial bearing. Our work studied the effectiveness of two particular chemical thinners (Accel and carbaryl) applied to three apple tree cultivars, and their effects on the fruit yield and quality. Materials and methods. Two identical experiments were undertaken on mature apple trees in 1995 and 1996. They made it possible to test spraying after flowering of Accel and carbaryl at three different concentrations and applied to the three 'Empire', 'JanA-Red' and 'Braeburn' apple tree cultivars. The effect of the chemical substances was evaluated with parameters of fruit set, fruit quality and yield. Results and discussion. For the three apple tree cultivars studied, the spraying of Accel and carbaryl made it possible to reduce the fruit set and to improve the apple yield, $\mathrm{pH}$ and soluble solids concentrations. However, the treatments did not affect the fruit seed number, the fruit length and diameter, or the [fruit length / fruit diameter] ratio. Conclusion. With the concentrations used, Accel and carbaryl were effective for thinning the three apple tree cultivars tested. These chemical thinners increased yield and improved certain parameters of the apple quality.

USA / Malus / varieties / cultivation / thinning / defruiting / chemical pruning / fruits / yields

\section{Réponse de plusieurs cultivars de pommiers à des traitements d'éclaircissage chimique.}

Résumé - Introduction. L'éclaircissage chimique de pommiers effectué après floraison est une pratique courante utilisée pour améliorer la dimension et la qualité du fruit, pour assurer le retour de floraison et pour réduire la production bisannuelle. Nos travaux ont étudié l'efficacité de deux éclaircisseurs chimiques (Accel et carbaryl) appliqués à trois cultivars de pommiers et leurs effets sur le rendement et la qualité du fruit. Matériel et méthodes. Deux mêmes expériences ont été menées sur des pommiers adultes en 1995 et 1996. Elles ont permis de tester la pulvérisation après floraison d'Accel et de carbaryl à trois concentrations différentes et appliquées aux trois cultivars de pommiers : 'Empire', 'Jan-A-Red' et 'Braeburn'. L'effet des substances chimiques a été évalué sur la nouaison, la qualité du fruit et le rendement des arbres. Résultats et discussion. Chez les trois cultivars de pommiers, la pulvérisation d'Accel et carbaryl a permis de réduire la nouaison et d'améliorer le rendement, le pH et le taux en sucres des pommes. Cependant, les traitements n'ont pas affecté le nombre de graines dans le fruit, la longueur et le diamètre du fruit, ni le rapport [longueur du fruit / diamètre du fruit]. Conclusion. Aux concentrations utilisées, les produits Accel et carbaryl ont été efficaces pour éclaircir les trois cultivars de pommiers expérimentés. Ces éclaircisseurs chimiques ont augmenté le rendement et amélioré certains paramètres de la qualité des pommes.

États-Unis / Malus / variété / pratique culturale / éclaircissage / suppression de fruits / taille chimique / fruits / rendement 


\section{Introduction}

Chemical fruit thinning of apples after bloom is a common practice carried out to improve fruit size and quality, assure return bloom and reduce biennial bearing [1]. The fruit size at harvest depends on earliness and the level of fruit thinning as long as tree vigor is adequate [2].

Thinning can be conducted at bloom time and during the early postbloom period [3]. However, strongly biennial apple cutivars may require both bloom and postbloom spray programs for adequate thinning [2].

Postbloom chemical thinners are generally believed to interfere with endogenous hormones which control the flow of nutrients to the developing fruit [2]. Embryo abortion may come before or occur simultaneously with fruit abscission but it is not regarded to be its cause. Fruit abscission will be increased by chemical stress of any kind which is applied to apple trees during the early period [2]. Chemical thinning of apples can be done by ethephon [4], gibberellins [5], benzyladenine [6], N-2-chloro-4-pyridylN-phenylurea (CPPU) [7], N-phenylmethylpurine-6-amine benzyladenine (Accel, Abbott laboratory, USA) [8], or $\mathrm{C}_{10} \mathrm{H}_{7} 00 \mathrm{CNH}-\mathrm{CH}_{3}$ (carbaryl) [9].

Most of the studies conducted previously on chemical thinning of apples are still inconclusive and are specific to particular apple cultivars and ecological and environmental settings. Further, Accel and carbaryl have not been adequately tested on 'Empire', 'Jon-A-Red' and 'Braeburn' apples.

A two-year study was therefore conducted to:

- find the effect of different rates of Accel and carbaryl on apple fruit set,

- find the effect of Accel and carbaryl on yield, fruit weight, seed number, soluble solids concentration, $\mathrm{pH}$, fruit length, diameter and the fruit length to diameter ratio.

\section{Materials and methods}

Two identical experiments were carried out in 1995 and 1996 using mature apple trees at the Mississippi State University Agricultural and Forestry Experimental Station (MAFES) at Pontotoc. The Ridge-Flatwoods Branch Experimental Station is located about 7 miles south of Pontotoc in the southern central part of Pontotoc county. The types of soil found at the station are classified as alfisol, ultisol, inceptisol and entisol orders with soils ranging from deep red and high in silt to gray with silt loam and finer-textured subsoils with expensive montmorillonite clay.

Before the spraying, chemicals were prepared according to the amounts necessary for being used as chemical thinners. Treatments were determined by calculating the active ingredients they contained. The amount of the chemicals to be added for each treatment was calculated from the known volume of the sprayer, then added to water in the sprayer and thoroughly mixed with it before spraying. Spraying of the thinners was conducted on calm, clear and dry days with temperatures of $14{ }^{\circ} \mathrm{C}$ (minimum) and $18{ }^{\circ} \mathrm{C}$ (maximum). The surfactant Tween 20 (Sigma chemical Co, St. Louis, USA) at $0.1 \%$ was mixed with the chemical thinners to act as a wetting agent. The trees were sprayed to dripping point at a rate of $4000 \mathrm{~L} \cdot \mathrm{ha}^{-1}$. The trees were sprayed with Accel at three concentrations: $(25,50$ and 75$) \mathrm{mg} \cdot \mathrm{L}^{-1}$, or with carbaryl at three concentrations: $(0.05,0.10$ and 0.20$) \%$. Each treatment was applied with a hand sprayer (FMC 252, Food Machinery Corp; Jonesboro, Ark.) The control trees were sprayed with water only.

The two experiments were started 2 weeks after the blossoming when the fruit was about $12 \mathrm{~mm}$ in diameter. The first experiment was started on April 12, 1995, and terminated on July 30, 1995 . The second experiment was started on May 15 , 1996, and terminated on August 30, 1996. The treatments were replicated three times in a completely randomized design with a factorial arrangement. The study was conducted on the three Empire, Braeburn and Jon-A-Red apple tree cultivars because they were the main cultivars grown at the Pontotoc experimental station and by Mississippi farmers (i.e., six treatments per cultivar and three trees per treatment, thus 
18 trees treated per cultivar + six control trees). Recommended cultural practices for commercial apple production, i.e., fertilization, weeding and pest and disease control, were applied. Fruit harvesting started at the beginning of August each year. We determined fruit set, yield, seed number, length and diameter of the fruits, total soluble solids and $\mathrm{pH}$.

Fruit set was determined by tagging four representative limbs of 12 to $15 \mathrm{~cm}$ in circumference before bloom for use in fruit set counts [10-12]. The number of fruits was counted after June drop (i.e., 1 month after application of the chemicals) and expressed as the number of fruits per limb cross-sectional area [10-12]; fruit weight and yield were recorded and the average fruit weight of 20 fruits per tree was calculated.

Juice was extracted from the apple fruits using a Mullinex juice extractor (Fisher Scientific, Spring Field, N.J.) and filtered. From the extracted juice, the total soluble solids concentrations (SSC) were determined using a Bausch and Lomb optical refractometer (Fisher Scientific, Spring Field, N.J.) and expressed in degrees Brix ( ${ }^{\circ}$ Brix) and $\mathrm{pH}$ was determined with a pHmeter. Fruit length and diameter were determined by laying the fruit end-to-end and side-by-side in a $\mathrm{v}$-shaped trough and measuring the total length and diameter using a hand caliper on a sample of 10 fruits; measurements were recorded in millimeters. The [fruit length / fruit diameter] ratios were then calculated.

The seed number per fruit was only determined in 1996 by dissecting the fruit at harvest. An average seed number was then determined.

The experimental design was completely randomized with a factorial arrangement of treatments. There were three trees per treatment, i.e., three trees per replication. All statistical analyses were carried out using the general linear model procedure of the statistical analysis system (SAS Institute, N.C.) [13] program package. Means were determined using the least significant difference (LSD) at $p \leq 0.05$.

\section{Results and discussion}

In 1995, all the chemical thinners significantly $(p \leq 0.05)$ reduced fruit set (table I). In 1996, carbaryl and Accel at all concentrations significantly reduced the fruit set of Empire and Jon-A-Red except at $25 \mathrm{mg} \cdot \mathrm{L}^{-1}$ (table II). The thinning effects of Accel and carbaryl as observed above have also been reported previously [8, 14-18]. Competition in the partitioning of metabolites to fruit tissues, causing reduction in growth and eventual activation of abscission mechanisms, is the probable cause of these thinning effects of Accel and carbaryl [19].

In 1995, the yield of Empire was not significantly $(p \leq 0.05)$ affected by Accel or carbaryl. The yield of Jon-A-Red was only increased by Accel at $50 \mathrm{mg} \cdot \mathrm{L}^{-1}$, while the remaining treatments had no effect (table I). The yield of Braeburn was only increased by carbaryl at $0.2 \%$ and by Accel at $50 \mathrm{mg} \cdot \mathrm{L}^{-1}$. In 1996 , carbaryl at $0.1 \%$ and Accel at $50 \mathrm{mg} \cdot \mathrm{L}^{-1}$ increased the yields of Empire, while the other treatments had no effect. The yield of Jon-A-Red and Braeburn was increased by all the treatments. Fruit size was generally increased by the chemical thinners because thinning of fruit increases size [20]. Thinning increases the leaf to fruit ratio because removing some of the fruits causes the remaining ones to become larger in size [20]. Yield is a function of such factors as flower bud number, and fruit number and size [21]. However, this has been controversial [10]. The findings of our study agree with those of Stiles [8], Wismer et al. [16] and Kaps and Cahoon [22], who reported increased yield from thinning, while they disagree with those of Hull et al. [17], Valenzuela [23], Blanco [24], Gambrell et al. [25] and Nielsen and Dennis [26], who reported decreased yields from thinning. The latter differences may be attributed to different experimental conditions under which the present study was undertaken.

Fruit length and diameter, and the fruit length to diameter ratio, were not significantly affected by the treatments and neither was the seed number in the fruits. Elongated fruit formation is caused by vigorous rootstock and heavy thinning or light bloom 
Table I.

Effect of chemical thinners (Accel and carbaryl) on characteristics of three apple cultivars grown at the Pontotoc Research and Extension Centre, Brazil, in 1995 ( ${ }^{*}$, significant at $p \leq 0.05$; ns, not significant).

\begin{tabular}{|c|c|c|c|c|c|c|c|c|c|}
\hline $\begin{array}{l}\text { Apple } \\
\text { cultivar }\end{array}$ & $\begin{array}{c}\text { Chemical } \\
\text { thinner }\end{array}$ & $\begin{array}{c}\text { Chemical } \\
\text { thinner } \\
\text { concentration }\end{array}$ & $\begin{array}{l}\text { Number of fruit } \\
\text { per crop section } \\
\text { limb area }\end{array}$ & $\begin{array}{c}\text { Yield } \\
\text { per tree } \\
(\mathrm{kg})\end{array}$ & $\begin{array}{l}\text { Mean fruit } \\
\text { weight } \\
\text { (g) }\end{array}$ & $\begin{array}{l}\text { Fruit } \\
\text { length } \\
(\mathrm{cm})\end{array}$ & $\begin{array}{l}\text { [Fruit length / } \\
\text { fruit diameter] } \\
\text { ratio }\end{array}$ & $\begin{array}{l}\text { Juice } \\
\mathrm{pH}\end{array}$ & $\begin{array}{l}{ }^{\circ} \text { Brix } \\
\text { of juice }\end{array}$ \\
\hline \multirow[t]{7}{*}{ Empire } & \multirow{3}{*}{$\begin{array}{c}\text { Carbaryl } \\
(\%)\end{array}$} & 0.05 & 8.33 & 5.60 & 1.70 & 5.90 & 0.83 & 4.97 & 12.00 \\
\hline & & 0.10 & 5.40 & 8.40 & 1.80 & 5.83 & 0.81 & 4.43 & 12.80 \\
\hline & & 0.20 & 3.13 & 9.60 & 1.80 & 6.43 & 0.83 & 4.42 & 13.30 \\
\hline & \multirow{3}{*}{$\begin{array}{c}\text { Accel } \\
\left(\mathrm{mg} \cdot \mathrm{L}^{-1}\right)\end{array}$} & 25 & 6.10 & 6.40 & 1.40 & 5.93 & 0.80 & 4.48 & 14.50 \\
\hline & & 50 & 4.23 & 5.60 & 1.60 & 6.03 & 0.80 & 4.42 & 14.60 \\
\hline & & 75 & 1.67 & 8.00 & 1.20 & 5.97 & 0.87 & 4.56 & 15.10 \\
\hline & Control & - & 11.67 & 4.60 & 1.26 & 5.60 & 0.82 & 4.31 & 12.60 \\
\hline \multirow[t]{7}{*}{ Jon-A-Red } & \multirow{3}{*}{$\begin{array}{c}\text { Carbaryl } \\
(\%)\end{array}$} & 0.05 & 7.40 & 0.80 & 0.54 & 5.90 & 0.83 & 4.57 & 13.00 \\
\hline & & 0.10 & 4.43 & 1.30 & 0.64 & 5.57 & 0.85 & 4.39 & 15.60 \\
\hline & & 0.20 & 3.03 & 4.20 & 0.94 & 6.43 & 0.85 & 4.34 & 16.00 \\
\hline & \multirow{3}{*}{$\begin{array}{c}\text { Accel } \\
\left(\mathrm{mg} \cdot \mathrm{L}^{-1}\right)\end{array}$} & 25 & 0.37 & 0.80 & 1.55 & 5.73 & 0.81 & 4.40 & 13.00 \\
\hline & & 50 & 2.07 & 8.50 & 1.60 & 5.87 & 0.88 & 4.40 & 15.00 \\
\hline & & 75 & 0.23 & 7.70 & 1.26 & 6.13 & 0.83 & 4.60 & 13.00 \\
\hline & Control & - & 12.68 & 0.80 & 1.14 & 6.40 & 0.88 & 4.28 & 13.00 \\
\hline \multirow[t]{7}{*}{ Braeburn } & \multirow{3}{*}{$\begin{array}{c}\text { Carbaryl } \\
(\%)\end{array}$} & 0.05 & 8.37 & 5.90 & 1.58 & 6.00 & 0.80 & 4.30 & 13.50 \\
\hline & & 0.10 & 6.07 & 10.50 & 1.58 & 6.30 & 0.85 & 4.51 & 14.10 \\
\hline & & 0.20 & 4.43 & 17.80 & 1.76 & 6.18 & 0.87 & 4.28 & 14.80 \\
\hline & \multirow{3}{*}{$\begin{array}{c}\text { Accel } \\
\left(\mathrm{mg} \cdot \mathrm{L}^{-1}\right)\end{array}$} & 25 & 4.00 & 11.20 & 1.14 & 5.63 & 0.84 & 4.47 & 13.10 \\
\hline & & 50 & 5.87 & 17.20 & 1.52 & 6.16 & 0.87 & 4.34 & 13.40 \\
\hline & & 75 & 1.43 & 8.80 & 1.83 & 6.37 & 0.87 & 4.48 & 13.50 \\
\hline & Control & - & 12.80 & 4.90 & 1.14 & 6.17 & 0.85 & 4.45 & 12.90 \\
\hline $\operatorname{LSD}(p \leq 0.05)$ & - & - & 1.41 & 7.80 & 0.19 & 0.69 & 0.06 & 0.24 & 0.06 \\
\hline \multicolumn{10}{|l|}{ Significance of $F$ tests: } \\
\hline Cultivar & - & - & * & * & * & ns & ns & * & * \\
\hline Chem. thin. & - & - & * & * & * & ns & ns & * & * \\
\hline Cultivar $\times$ chem. thin. & - & - & * & * & * & ns & ns & * & * \\
\hline
\end{tabular}

resulting in a light crop. Fruit shape is affected by chemical thinners differently, e.g., gibberellins and some cytokinins increase fruit length [27], while kinetin and auxin do not affect fruit shape [20]. Since we did not get any significant effect of Accel and carbaryl on fruit length and diameter, or the fruit length to diameter ratio, we can classify them with the chemical thinners which do not affect fruit shape.
In 1995, the apple juice total soluble solids concentration was significantly $(p \leq$ 0.05 ) increased by all treatments except carbaryl at $0.05 \%$ (table I). In 1996, the Brix of Empire and Jon-A-Red was significantly increased by all the concentrations of Accel and by carbaryl at $0.2 \%$ for Empire and at $0.1 \%$ and $0.2 \%$ for Jon-A-Red. Only carbaryl at $0.1 \%$ and Accel at $(50$ and 75$) \mathrm{mg} \cdot \mathrm{L}^{-1}$ had an effect on the fruit juice soluble 
Table II.

Effect of chemical thinners (Accel and carbaryl) on characteristics of three apple cultivars grown at the Pontotoc Research and Extension Centre, Brazil, in 1996 ( ${ }^{*}$, significant at $p \leq 0.05$; ns, not significant).

\begin{tabular}{|c|c|c|c|c|c|c|c|c|c|c|}
\hline $\begin{array}{l}\text { Apple } \\
\text { cultivar }\end{array}$ & $\begin{array}{l}\text { Chemical } \\
\text { thinner }\end{array}$ & $\begin{array}{c}\text { Chemical } \\
\text { thinner } \\
\text { concentration }\end{array}$ & $\begin{array}{l}\text { Number of fruit } \\
\text { per crop section } \\
\text { limb area }\end{array}$ & $\begin{array}{l}\text { Yield } \\
\text { per tree } \\
(\mathrm{kg})\end{array}$ & $\begin{array}{l}\text { Mean fruit } \\
\text { weight } \\
\text { (g) }\end{array}$ & $\begin{array}{l}\text { Fruit } \\
\text { length } \\
\text { (cm) }\end{array}$ & $\begin{array}{c}\text { [Fruit length / } \\
\text { Fruit diameter] } \\
\text { ratio }\end{array}$ & $\begin{array}{l}\text { Juice } \\
\text { pH }\end{array}$ & $\begin{array}{l}{ }^{\circ} \text { Brix } \\
\text { of juice }\end{array}$ & $\begin{array}{l}\text { Number } \\
\text { of seeds }\end{array}$ \\
\hline \multirow[t]{7}{*}{ Empire } & \multirow{3}{*}{$\begin{array}{c}\text { Carbaryl } \\
(\%)\end{array}$} & 0.05 & 9.47 & 4.57 & 1.40 & 5.21 & 0.91 & 4.09 & 12.07 & 6.33 \\
\hline & & 0.10 & 4.63 & 21.27 & 0.90 & 5.59 & 0.84 & 4.25 & 12.20 & 6.66 \\
\hline & & 0.20 & 0.23 & 5.43 & 1.53 & 5,84 & 0.82 & 4.24 & 13.77 & 6.67 \\
\hline & \multirow{3}{*}{$\begin{array}{c}\text { Accel } \\
\left(\mathrm{mg} \cdot \mathrm{L}^{-1}\right)\end{array}$} & 25 & 13.97 & 9.37 & 1.14 & 5.63 & 0.80 & 3.76 & 13.40 & 6.66 \\
\hline & & 50 & 7.73 & 23.87 & 1.55 & 5.27 & 0.86 & 4.22 & 13.67 & 6.33 \\
\hline & & 75 & 3.57 & 13.10 & 1.63 & 6.04 & 0.78 & 4.24 & 14.00 & 7.00 \\
\hline & Control & - & 14.60 & 3.63 & 1.33 & 5.77 & 0.86 & 4.28 & 11.60 & 6.67 \\
\hline \multirow[t]{7}{*}{ Jon-A-Red } & \multirow{3}{*}{$\begin{array}{l}\text { Carbaryl } \\
(\%)\end{array}$} & 0.05 & 4.43 & 23.43 & 1.13 & 5.28 & 0.80 & 3.52 & 12.97 & 5.66 \\
\hline & & 0.1 & 1.80 & 21.77 & 1.27 & 5.43 & 0.84 & 3.97 & 13.77 & 6.33 \\
\hline & & 0.2 & 1.63 & 23.47 & 1.27 & 5.40 & 0.79 & 3.97 & 13.77 & 6.33 \\
\hline & \multirow{3}{*}{$\begin{array}{c}\text { Accel } \\
\left(\mathrm{mg} \cdot \mathrm{L}^{-1}\right)\end{array}$} & 25 & 7.40 & 9.73 & 1.27 & 5.43 & 0.86 & 3.97 & 13.17 & 6.33 \\
\hline & & 50 & 2.43 & 37.10 & 1.65 & 5.47 & 0.85 & 4.42 & 13.53 & 7.00 \\
\hline & & 75 & 0.83 & 37.10 & 1.65 & 5.37 & 0.86 & 4.42 & 13.53 & 7.00 \\
\hline & Control & - & 8.20 & 2.97 & 1.07 & 5.67 & 0.80 & 3.76 & 11.67 & 5.33 \\
\hline \multirow[t]{7}{*}{ Braeburn } & \multirow{3}{*}{$\begin{array}{l}\text { Carbaryl } \\
(\%)\end{array}$} & 0.05 & 7.67 & 17.30 & 1.03 & 5.86 & 0.87 & 4.01 & 12.77 & 6.33 \\
\hline & & 0.1 & 5.60 & 22.30 & 1.50 & 5.90 & 0.87 & 4.65 & 14.40 & 6.33 \\
\hline & & 0.2 & 1.37 & 18.87 & 1.67 & 6.03 & 0.84 & 4.16 & 12.97 & 7.30 \\
\hline & \multirow{3}{*}{$\begin{array}{c}\text { Accel } \\
\left(\mathrm{mg} \cdot \mathrm{L}^{-1}\right)\end{array}$} & 25 & 6.73 & 21.33 & 1.40 & 5.93 & 0.83 & 4.00 & 12.13 & 6.00 \\
\hline & & 50 & 4.97 & 21.47 & 1.62 & 5.45 & 0.76 & 4.59 & 13.70 & 7.00 \\
\hline & & 75 & 0.73 & 29.03 & 1.69 & 6.16 & 0.84 & 4.74 & 14.00 & 7.00 \\
\hline & Control & - & 12.33 & 6.00 & 0.95 & 5.93 & 0.83 & 4.03 & 12.07 & 5.30 \\
\hline $\operatorname{LSD}(p \leq 0.05)$ & - & - & 4.03 & 10.61 & 1.19 & 0.61 & 0.15 & 0.50 & 1.46 & 0.30 \\
\hline \multicolumn{11}{|l|}{ Significance of $\mathrm{F}$ test: } \\
\hline Cultivar & - & - & ns & ns & ns & ns & ns & ns & ns & ns \\
\hline Chemical thinners & - & - & * & * & ns & ns & ns & ns & * & ns \\
\hline Cultivar $\times$ chem. thin. & - & - & * & ns & ns & ns & ns & ns & ns & ns \\
\hline
\end{tabular}

solids concentration of Braeburn (table II). These observations may be explained by the effect of the thinners on the leaf to fruit ratio, and hence on the flow of the photosynthates.

In 1995, carbaryl at $0.05 \%$ and Accel at $75 \mathrm{mg} \cdot \mathrm{L}^{-1}$ significantly $(p \leq 0.05)$ increased the $\mathrm{pH}$ of apple juice for Empire and Jon-
A-Red, while the rest of the treatments had no significant effect (table I). In 1996, the $\mathrm{pH}$ of Empire was significantly reduced by Accel at $25 \mathrm{mg} \cdot \mathrm{L}^{-1}$, while the other chemical thinners had no effect on the $\mathrm{pH}$ of this cultivar. The $\mathrm{pH}$ of Jon-A-Red was increased by Accel at (50 and 75) $\mathrm{mg} \cdot \mathrm{L}^{-1}$, while that of Braeburn was increased by carbaryl at $0.1 \%$ and Accel at (50 and 75) $\mathrm{mg} \cdot \mathrm{L}^{-1}$ (table II). 
For this characteristic, it seems that the effect of chemical thinners was cultivar-specific and strongly influenced by the year of experimentation.

\section{Conclusions}

The study demonstrated that Accel and carbaryl could be used effectively for thinning of the Empire, Braeburn and Jon-A-Red apple cultivars at certain concentrations. Indeed, these chemical thinners could increase the apple juice total soluble solids concentration but did not affect fruit length, diameter or the fruit length to diameter ratio. Accel and carbaryl at the concentration used in our work showed no effect on the fruit seed number and had a variable effect on fruit $\mathrm{pH}$.

\section{Acknowledgements}

The grants for the study from USAID are gratefully acknowledged.

\section{References}

[1] Looney N.E., Chemical thinning of apples. Some new strategies and important refinements to old procedures, Acta Hortic. 179 (1986) 597-604.

[2] Williams M.W., Chemical thinning of apples, in: Janick J. (Ed.), Hortic. Rev., Avi publishing company, USA, 1979.

[3] Fallahi E., Lee R.R., Lee G.A., Commercial scale use of hydrogen cyanamide for apple and peach blossom thinning, HortTechnology 8 (4) (1998) 556-560.

[4] Jones K.M, Koen T.B., Oakford M.J., Bound S., Thinning 'Red Fuji' apples with ethephon or NAA, J. Hortic. Sci. 64 (5) (1989) 527-532.

[5] Cohen R.A., Greene D.W., $\mathrm{GA}_{4}, \mathrm{GA}_{7}$, and benzyladenine influence fruitset, fruit quality and return bloom of Golden Delicious apples, HortScience 23 (3) (1988) 788-789.
[6] Greene D.W., A review of the use of benzyladenine $(B A)$ as a chemical thinner for apples, Acta Hortic. 329 (1993) 231-236.

[7] Bound S.A., Jones K.M., Koen T.B., Oakford M.J., The thinning effect of benzyladenine on 'red Fuji' apple trees, J. Hortic. Sci. 66 (6) (1991) 789-794.

[8] Stiles W.C., 'Empire' apple tree responses to fruit thinning chemicals, Hortscience 30 (40) (1995) 765.

[9] Mahhou A., Achachl K., Éclaircissage chimique du pommier (Malus domestica L. Borkh) dans la région de Meknes au Maroc, Fruits 57 (2) (2002) 115-127.

[10] Forshey C.G., Elfving D.C., Fruit numbers, fruit size and yield relationships in 'McIntosh' apples, J. Am. Soc. Hortic. Sci. 102 (4) (1977) 399-402.

[11] Forshey C.G., Elfving D.C., Branch samples for yield and fruit size comparisons in apple, HortScience 14 (2) (1979) 143-144.

[12] Lombard P.B., Callan N.W., Dennis F.G. Jr., Looney N.E., Martin G.C., Renquist A.R., Mielke E.A., Towards a standardized nomenclature, procedures, values, and units in determining fruit and nut tree yield performance, 23 (5) (1988) 813-817.

[13] Anonymous, Statistical Analysis Guide, SAS Institute, Cory, NC, USA, 1988.

[14] Williams M.W., Comparison of NAA and carbaryl petal-fall sprays on fruit set of apples, HortTechnology 3 (4) (1993) 428-429.

[15] Elfving D.C., Cline R.A., Benzyladenine and other chemicals for thinning 'Empire' apple trees, J. Am. Soc. Hortic. Sci. 118 (5) (1993) 593-598.

[16] Wismer P.T., Proctor J.T.A., Elfving D.C., Benzyladenine affects cell division and cell size during apple fruit thinning, J. Am. Soc. Hortic. Sci. 120 (5) (1995) 802-807.

[17] Hull J. Jr., Bukovac M.J. Bukovac B.C., Black B.L., Effect of concentration and time of Accel application on cropping of selected cultivars, HortScience 30 (4) (1995) 765.

[18] Black B.L., Bukovac M.J., Stopar M., Growth response of apple fruit to NAA and Accel, effect of intraspur competition and position on spur, HortScience 30 (4) (1993) 456. 
[19] Knight J.N., Fruit thinning of the apple cultivar 'Cox's Orange Pippin', J. Hortic. Sci. 55 (3) (1980) 267-273.

[20] Westwood M.N., Temperate-zone pomology: physiology and culture, Timber Press, Portland, Oregon, USA, 1993, pp. 259-269.

[21] Davis F., Flower position, growth regulators and fruitset of Rabbiteye Blueberries, J. Am. Soc. Hortic. Sci. 3 (1986) 338-341.

[22] Kaps M.L., Cahoon G.A., Berry thinning and cluster thinning influence vegetative growth, yield, fruit composition and net photosynthesis of 'Seyual Blanc' grapes, J. Am. Soc. Hortic. Sci. 114 (1) (1989) 20-24.

[23] Valenzuela J.R.C., Regulating blueberry (Vaccinium ashei Read) crop, thesis, Missis- sippi State University, Mississippi State, USA, 1992.

[24] Blanco A., Fruit thinning of peach trees Prunus persica (L.) Batch.: the effect of paclobutrazol on fruit drop and shoot growth, J. Hortic. Sci. 62 (2) (1987) 147-155.

[25] Gambrell C.E. Jr., Custom D.C., Sims E.T. Jr., Results of eight years with CGA -15281 as a postbloom thinner for peaches, J. Am. Soc. Hortic. Sci. 108 (4) (1983) 605-608.

[26] Nielsen J.C., Dennis F.G., Thinning 'Delicious' apples, trials and tribulations, HortScience 28 (1993) 484.

[27] Williams M.W., Stahly E.A., Effect of cytokinin and GA on the shape of 'Delicious' apple fruits, J. Am. Soc. Hortic. Sci. 94 (1969) $17-19$.

\section{Respuesta de algunos cultivares de manzano a tratamientos de raleo químico.}

Resumen - Introducción. El raleo químico del manzano tras la floración es una práctica habitual empleada para mejorar el tamaño y la calidad del fruto, para garantizar el retorno de floración y reducir la producción bienal. Nuestro trabajo estudió la eficacia de dos raleadores químicos (Accel y carbaril) aplicados a tres cultivares de manzano y sus efectos en el rendimiento y la calidad del fruto. Material y métodos. Se efectuaron dos experimentos similares en manzanos adultos en 1995 y 1996 que permitieron probar la pulverización, tras floración, de Accel y carbaril con tres concentraciones distintas aplicadas a tres cultivares de manzano: 'Empire', 'Jan-A-Red' y 'Braeburn'. Se evaluó el efecto de las sustancias químicas en el cuajado, la calidad del fruto y el rendimiento de los árboles. Resultados y discusión. La pulverización de Accel y carbaril permitió reducir el cuajado y mejorar el rendimiento, el pH y el nivel de azucares de las manzanas de los tres cultivares. Sin embargo, los tratamientos no afectaron al número de semillas del fruto, ni la longitud y el diámetro ni la relación [longitud del fruto / diámetro del fruto]. Conclusión. En las concentraciones utilizadas, Accel y carbaril se mostraron eficaces para el aclareo de los tres cultivares de manzano probados. Estos raleadores químicos aumentaron el rendimiento y mejoraron algunos parámetros de calidad de las manzanas.

EUA / Malus / variedades / cultivo / aclareo / supresión de frutos / poda química / frutas / rendimiento 